\title{
Biomechaniczne aspekty leczenia stomatologicznego z użyciem kompozytów wzmocnionych włóknem (FRC)
}

\section{Biomechanical aspects of dental treatment using fiber-reinforced composites (FRC)}

Klinika Gerostomatologii i Patologii Jamy Ustnej, Uniwersytet Medyczny im. Karola Marcinkowskiego w Poznaniu

DOI: http://dx.doi.org/10.20883/df.2018.24

\begin{abstract}
STRESZCZENIE
Wysoka wytrzymałość i niewielka masa sprawiają, że materiały kompozytowe wzmocnione włóknem (FRC) są coraz chętniej stosowane w leczeniu pacjentów z częściowymi lub całkowitymi brakami zębowymi. Tego typu materiały mogą być z powodzeniem racjonalnie stosowane w zmiennym, trudnym i zróżnicowanym środowisku jamy ustnej stając się często skuteczną alternatywą dla innych, często droższych, rozwiązań protetycznych. Nieustanne pogłębianie wiedzy z tego zakresu niewątpliwie ułatwi uzyskanie zadowalających pod względem klinicznym i ekonomicznym uzupełnień protetycznych wykonanych z FRC. W oparciu o dane zawarte w recenzowanych artykułach naukowych dokonano przeglądu wiedzy z tego zakresu ze szczególnym uwzględnieniem właściwości biomechanicznych tej grupy materiałów stomatologicznych.
\end{abstract}

Słowa kluczowe: właściwości mechaniczne, kompozyt wzmocniony włóknem (FRC), przegląd piśmiennictwa.

\section{ABSTRACT}

The high strength and the low weight of fiber-reinforced composite (FRC) materials make them more desirable in the treatment of patients with partial or complete dentures. Based on data from peer-reviewed scientific journals, the factors affecting the mechanical properties of these materials were reviewed. It was found that adhesive polymeric materials reinforced with various types of fibers can be successfully used in a demanding and diversified oral environment. The continuous improvement of knowledge in this field will undoubtedly facilitate the achievement of clinically and economically satisfactory prosthetic restorations made from FRC.

Keywords: Mechanical proprities, fiber-reinforced composites (FRC), review.

\section{Wprowadzenie}

Tworzywa kompozytowe wzmocnione włóknem (ang. fiber reinforced composites, FRC) to grupa lekkich materiałów syntetycznych o szerokim zakresie wskazań klinicznych, umożliwiająca trwałą odbudowę utraconych tkanek zęba. Wysoka wytrzymałość oraz niewielka masa spoczynkowa tych materiałów sprawiają, że możliwym staje się efektywne przenoszenie naprężeń generowanych cyklicznie w układzie stomatognatycznym. Dlatego też FRC znalazły szerokie zastosowanie, jako metoda z wyboru, w wielu dziedzinach stomatologii takich jak protetyka stomatologiczna, stomatologia zachowawcza, implantologia, periodontologia, ortodoncja, stomatologia dziecięca.

FRC to materiał złożony z włókien (faza wzmacniająca) oraz z żywicznej macierzy polimerowej (faza organiczna). Macierz polimerowa stanowi osnowę dla włókien wzmacniających, chroni je przed urazem zgryzowym i przekazuje na nie przyłożone naprężenia zewnętrzne. Ponadto żywica polimerowa łączy się z cementem lutującym i nadaje materiałowi pożądany kształt.

Wprowadzenie włókien charakteryzujących się wysokim modułem sprężystości do miękkiej lecz ciągliwej matrycy poprawia wytrzymałość oraz sztywność materiału, zapewniając kompozytowi wysokie właściwości mechaniczne w selektywnych kierunkach. Możliwym stało się ich długoczasowe obciążenie w sytuacjach, w których do tej pory zalecane było zastosowanie wyłącznie konwencjonalnych protez stałych.

\section{Czynniki wpływające na właściwości materiałów FRC}

Postęp technologiczny $w$ inżynierii materiałowej sprawił, że materiały FRC mogą być racjonalnie wykorzystane $w$ wielu aspektach życia codziennego, 
nierzadko w zmiennych, trudnych i zróżnicowanych warunkach, także w środowisku jamy ustnej.

Przy relatywnie małej, w stosunku do lekkich stopów metali, gęstości, czyli przy niewielkiej masie, uzyskano bardzo wysokie wartości wytrzymałości względnej. Materiały kompozytowe na osnowach polimerowych wzmacniane włóknami stały się niezastąpione w wielu gałęziach przemysłu m.in. w produkcji kamizelek kuloodpornych, konstrukcji bolidów Formuły 1, rakiet tenisowych, ram rowerowych, w konstrukcjach lotniczych oraz kosmicznych. W stomatologii stosowane są przede wszystkim w wykonawstwie cementowanych adhezyjnie wypełnień ubytków tkanek twardych pojedynczego zęba bądź też rozległych braków rozdzielających łuki zębowe za pomocą stałych i ruchomych protez dentystycznych. Występujące naturalnie w przyrodzie włókna, produkowane z surowców pochodzenia roślinnego (bawełna, len, konopie, sizal) oraz zwierzęcego (wełna, jedwab) nie znalazły do tej pory klinicznego zastosowania w medycynie, głównie przez wzgląd na słabą odporność mechaniczną oraz dużą chłonność wody, skutkującą pogarszaniem się parametrów użytkowych takich włókien w czasie ich eksploatacji w środowisku o podwyższonej wilgotności.

Poniżej przedstawiono czynniki wpływające na właściwości mechaniczne materiałów FRC. Parametry te zostały przybliżone $\mathrm{w}$ opracowaniu powstałym w oparciu o dane publikowane $w$ recenzowanych artykułach poglądowych oraz w oryginalnych pracach badawczych [1].

\section{Właściwości poszczególnych faz (osnowy izbrojenia)}

Wśród włókien zbrojących materiały stomatologiczne wyróżnić można następujące ich rodzaje: włókna szklane, polietylenowe oraz poliaramidowe. Włókna węglowe/grafitowe nie są powszechnie stosowane ze względu na szary kolor, niepożądany w leczeniu stomatologicznym.

Charakteryzują się one liniową zależnością naprężenie-odkształcenie, przy czym mają różną wytrzymałość na rozciąganie. Gęstość jest istotną cechą fizyczną włókien, ponieważ decyduje ona o masie kompozytu, co przekłada się na obniżenie ciężaru protezy. Najniższą jej wartość, wynoszącą $1,45 \mathrm{~g} / \mathrm{cm}^{3}$ mają włókna polietylenowe, wyższą wartość - równą $1,8 \mathrm{~g} / \mathrm{cm}^{3}$ - wykazują włókna aramidowe, natomiast włókna szklane charakteryzują się najwyższą wartością tego parametru, osiągającą $2,5 \mathrm{~g} / \mathrm{cm}^{3}$. Wybrane właściwości mechaniczne, które mogą różnić się w zależności od producenta, zostały przedstawione $w$ tabeli 1.

Chętnie wykorzystywane w produkcji materiałów stomatologicznych, ze względu na transparencję oraz budowę chemiczną, są włókna szklane. Dzięki procesowi silanizacji zapewnione jest trwałe połączenie zbrojenia z macierzą organiczną $[5,6]$.

Włókna te charakteryzuje duża wytrzymałość i niewielkie wydłużenie przy zerwaniu. W środowisku wodnym wytrzymałość włókien może się obniżyć, szczególnie jeśli w składzie występują tlenki metali silnie zasadowe [7].

Włókna polietylenowe o ultra dużej masie cząsteczkowej (ang. Ultra High Molecular Weight Polyethylene, UHMWPE) charakteryzują się niską absorpcją wilgoci. Nie ulegają hydrolizie, a zatem ich właściwości są stabilne w środowisku o podwyższonej wilgotności [8]. Dużym postępem technologicznym było uzyskanie, w wyniku wtłaczania i rozciągania polietylenu, włókna o wyjątkowym uporządkowaniu łańcucha. Polimer budujący strukturę włókna polietylenowego tworzy równolegle ułożone łańcuchy o stopniu zorientowania > 95\% i krystaliczności > 85\%, co odróżnia go od włókien para-aramidowych, których wytrzymałość wynika głównie z dużej ilości międzycząsteczkowych wiązań wodorowych [9].

Wzmocnienie włóknami jest bardzo efektywne. Poprawę właściwości mechanicznych i termicznych można uzyskać już przy zwiększeniu zawartości włókien w stosunku do organicznej osnowy polimerowej o $10 \%$.

Równie ważne, choć występujące w znacznie mniejszych ilościach, są czynniki zwiększające ad-

Tabela 1. Rodzaje włókien stosowanych w stomatologii

Table 1. Types of fibers used in dentistry

\begin{tabular}{|l|c|c|c|c|}
\cline { 2 - 4 } \multicolumn{1}{c|}{} & \multicolumn{2}{c|}{ Szklane (1) } & \multirow{2}{*}{ Aramidowe (2) } & \multirow{2}{*}{ Polietylenowe (3) } \\
\cline { 2 - 5 } \multicolumn{1}{c|}{} & $\mathrm{E}$ & $\mathrm{S}$ & & \\
\hline Gęstość & $2460 \mathrm{~kg} / \mathrm{m}^{3}$ & $2490 \mathrm{~kg} / \mathrm{m}^{3}$ & $1,40-1,47 \mathrm{~g} / \mathrm{cm}^{3}$ & $970-980 \mathrm{~kg} / \mathrm{m}^{3}$ \\
\hline Twardość w skali Mohsa & $6,0^{\circ}$ & - & - & - \\
\hline Wytrzymałość na rozciąganie w temp. $25^{\circ} \mathrm{C}$ & $3500 \mathrm{MPa}$ & $4500 \mathrm{MPa}$ & $700-3450 \mathrm{MPa}$ & $3000 \mathrm{GPa}$ \\
\hline Moduł sprężystości w temp. $25^{\circ} \mathrm{C}$ & $73,5 \mathrm{GPa}$ & $86,5 \mathrm{GPa}$ & $17-179 \mathrm{GPa}$ & $116 \mathrm{GPa}$ \\
\hline
\end{tabular}


hezję pomiędzy matrycą i wypełniaczem a także inicjatory polimeryzacji. Matryca organiczna większości dostępnych komercyjnie FRC składa się z mieszaniny monomerów metakrylowych. Stosowane są dwa główne monomery - Bis-GMA (dimetakrylan eteru diglicydowego bisfenolu A) oraz UDMA (dimetakrylan uretanu), a także monomery o mniejszej lepkości, takie jak TEGDMA (dimetakrylan glikolu trietylenowego) czy HEMA (metakrylan 2-hydroksyetylu). Stosowanie tych drugich spowodowane jest koniecznością rozcieńczenia niezwykle lepkich Bis-GMA czy UDMA w celu umieszczenia w matrycy największej możliwej ilości napełniacza. Dimetakrylany odpowiedzialne są za tworzenie sieciowania, a PMMA (polimetakrylan metylu) tworzą struktury liniowe. Utwardzanie materiałów kompozytowych przeprowadza się na drodze reakcji polimeryzacji inicjowanej chemicznie, termicznie lub za pomocą światła [10-12].

\section{Geometria}

\section{Uporzq̨dkowanie (orientacja) włókien}

Włókna mogą występować w układzie ciągłym (ang. continuous) lub rozproszonym (ang. discontinuous), czyli w postaci odcinków pociętych na mniejsze fragmenty. W materiale kompozytowym włókna mogą być ułożone w formie wzdłużnie zorientowanej wiązki (ang. unidirectional), w postaci taśm ułożonych dwukierunkowo (ang. bidirectional) lub tworząc trójwymiarową sieć przypadkowo rozmieszczonych włókien wielokierunkowych (ang. random oriented) (Rycina 1).

Wiązki włókien ciągłych ułożonych jednokierunkowo są anizotropowe, to znaczy że posiadają różne właściwości w zależności od kierunku działającej siły, włókna rozmieszczone dwukierunkowo zapewniają właściwości ortotropowe, tzn. że są takie same $w$ dwóch kierunkach i różne $w$ trzecim (ortogonalnym) kierunku, skierowanym prostopadle do dwóch poprzednich. Włókna ułożone przypadkowo zapewniają materiałowi właściwości izotropowe, a więc różne $w$ zależności od kierunku działania siły.

Różne ułożenie włókien tego samego rodzaju w osnowie kompozytowej ma wpływ na właściwości mechaniczne materiału. Ułożenie prostopadłe wiązki włókien w stosunku do działających sił zgryzowych zapewnia właściwe i pożądane wartości ugięcia, wytrzymałości na zginania, a ryzyko pękania macierzy będzie w tym kierunku największe. W sytuacji gdy siły skierowane są w kierunku prostopadłym do długiej osi włókien znajdujących się w położeniu jednokierunkowym, rosnąć będzie udział żywicy w przenoszeniu obciążeń. Jednocze- śnie włókna w takim ułożeniu w minimalnym stopniu będą zmieniać właściwości macierzy organicznej [13]. Taka architektura zapewnia optymalne warunki przenoszenia sił między osnową polimerową a włóknem. Sztywność, czyli odporność na zginanie jest wówczas największa [14]. Tego typu rozwiązanie, a więc wzdłużne i jednokierunkowe ułożenie włókien zalecane jest $\mathrm{w}$ przypadku protez stałych, wykonanych z FRC [15].

Anizotropia właściwości jest duża w przypadku kompozytów jednokierunkowych. Moduł sprężystości w kierunku prostopadłym do długości włókien jest zbliżony do modułu osnowy, czyli wielokrotnie mniejszy niż włókien. Stąd konieczność budowy konstrukcji warstwowych (laminatów), w których włókna są rozłożone pod różnymi kątami, dając pozorną (quasi) izotropię materiału w płaszczyźnie materiału bądź stosowania włókien krótkich, ułożonych $w$ materiale $w$ porządku rozproszonym [15].

\section{Wymiary (średnica i długość) włókna}

Właściwości wytrzymałościowe włókna są uzależnione od jego średnicy. Badania statystyczne pokazują, że wytrzymałość włókien o małych średnicach jest większa niż włókien o średnicy przekraczającej pewną graniczną wartość. Wyraźny wzrost wytrzymałości odpowiada zwykle średnicy włókna nie przekraczającej $15 \mu \mathrm{m}$.

Powyżej tej wartości wzrasta prawdopodobieństwo pojawienia się wad powierzchniowych, takich jak mikropęknięcia i uskoki. Zastosowanie włókien, których średnica mierzona jest w skali nanometrycznej $\left(10^{-9} \mathrm{~m}\right)$, czyli na poziomie pojedynczych atomów i cząsteczek zapewnia większą wytrzymałość niż włókien o średnicy mierzonej w skali mikrometrycznej $\left(10^{-6} \mathrm{~m}\right)$. Stosowane obecnie $w$ stomatologii włókna standardowo charakteryzują się średnicą 6-16 $\mu \mathrm{m}$ [16].

$\mathrm{Na}$ właściwości mechaniczne kompozytu w istotny sposób wpływ ma także długość włókna. Jeżeli długość włókien ciętych będzie dostatecznie duża, to otrzymany produkt może charakteryzować się podobną sztywnością i wytrzymałością, jak w przypadku włókien ciągłych. Warunek jest tylko jeden, długość włókna musi być większa od tzw. długości krytycznej. Krytyczna długość włókna definiowana jest jako minimalna długość (dla danej średnicy), przy której zniszczenie kompozytu następuje wskutek pęknięcia rozciąganego włókna, a nie przez ścinanie na granicy włókna i osnowy. Jest to minimalna długość włókna, która zapewnia materiałowi właściwości wzmacniające. Przyjmuje się, że długość włókna powinna być 


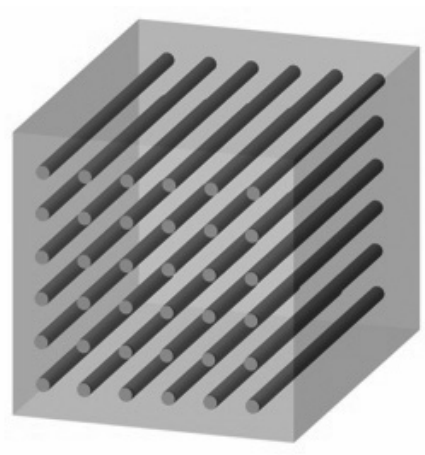

A

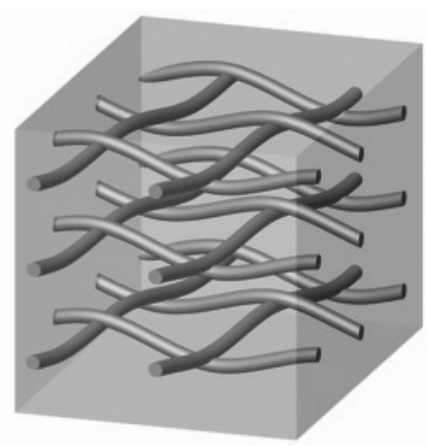

B

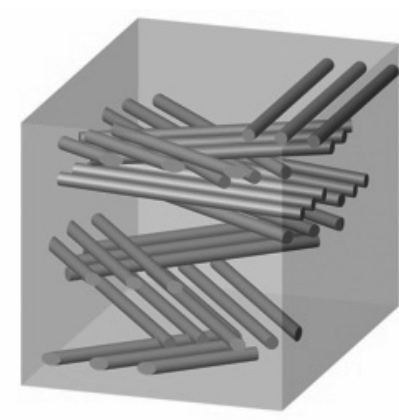

C

Rycina 1. Orientacja włókien: A - jednokierunkowa, B - dwukierunkowa, $C$ - wielokierunkowa, włókna ułożone w przypadkowej kolejności

Figure 1. Fibers orientation: $A$ - unidirectional, $B$ - bidirectional, $C$ - multidirectional, fibers arranged in random order

50 razy większa od jego średnicy. Średnica włókien szklanych stosowanych w stomatologii wynosi 15$18 \mu \mathrm{m}$, stąd też krytyczna długość takiego włókna powinna wynosić $0,75-0,9 \mathrm{~mm}$ [17].

Wraz z wydłużeniem włókna jego efektywność rośnie liniowo w początkowej fazie trwania eksperymentu, w dalszej części przebieg funkcji jest wykładniczy. Dalsze wydłużanie wiązki nie przynosi wówczas poprawy właściwości wytrzymałościowych (Rycina 2).

Wytrzymałość i moduł elastyczności materiału FRC zależy od ilości użytych włókien w stosunku ilości macierzy organicznej, a więc od względnej zawartości poszczególnych faz - osnowy i zbrojenia. Poprawę parametrów wytrzymałościowych można uzyskać poprzez zastosowanie większej ilości włókien w jednostce objętości, ale o mniejszej średnicy. Na podstawie wyników otrzymanych $z$ badań mechanicznych, przeprowadzonych przez Lassila i wsp., otrzymano zależność udziału objętościowego włókien z wybranymi właściwościami mechanicznymi, tj. wytrzymałość i moduł sprężystości wzdłużnej. Zaobserwowano, że wymienione parametry wytrzymałościowe wzrastają wraz ze wzrostem objętości włókien, osiągając swoje maksimum w objętości włókien równej $68 \%$. Powyżej

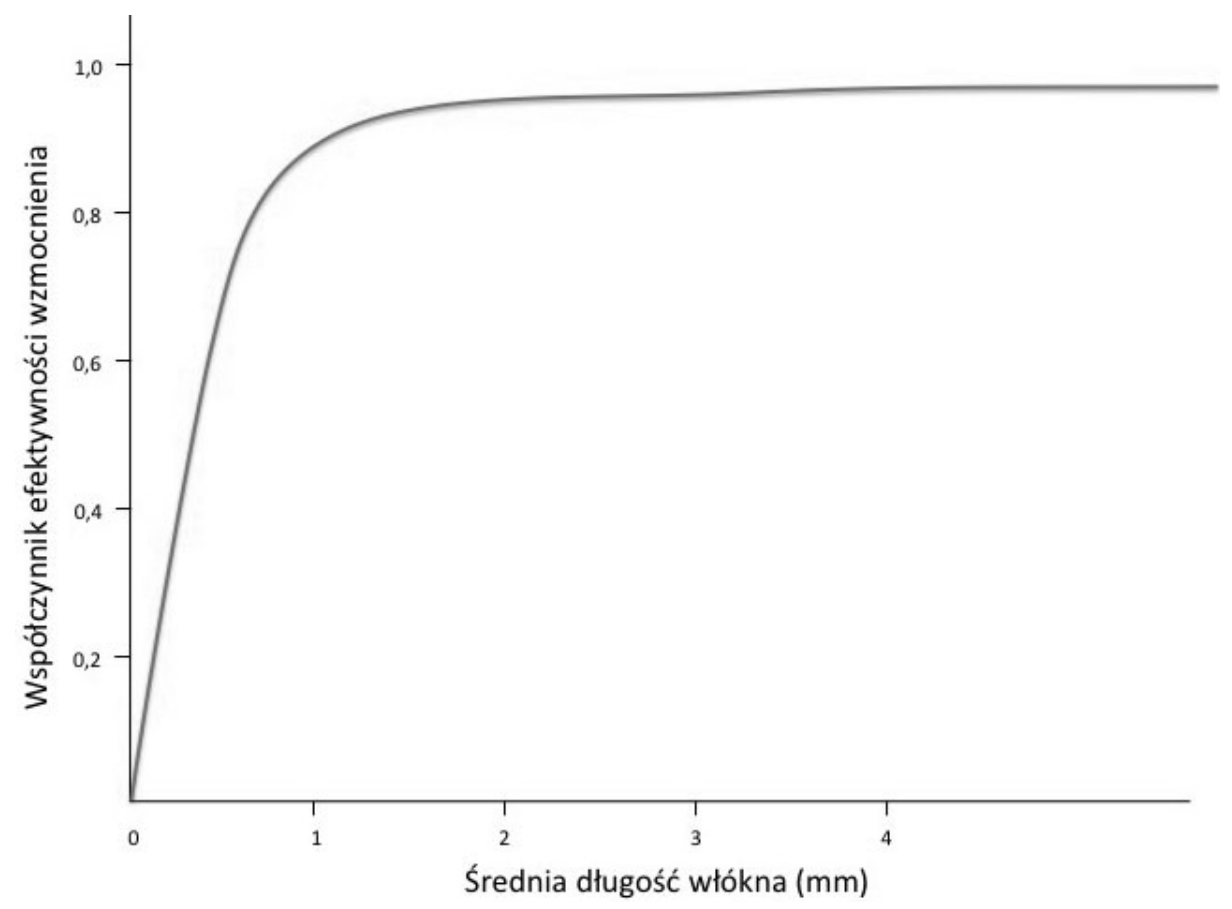

Rycina 2. Wpływ długości włókna na efektywność wzmocnienia materiałów FRC

Figure 2. The influence of fiber length on the effectiveness of reinforcement of FRC materials 
68\% udziału objętościowego włókien wytrzymałość i moduł Younga zaczynają spadać, aż do zerwania (Rycina 3) [18].

\section{Kształt włókna na przekroju poprzecznym}

Włókna elementarne różnią się między sobą nie tylko składem chemicznym, lecz również na przekroju poprzecznym. Najpopularniejsze to te o przekroju kołowym, ale produkowane są również włókna o przekroju trójkątnym, prostokątnym oraz włókna rurkowe. Jako wypełnienie stosuje się też włókno w postaci mikrosfer i mikrobaloników. Włókna, które na przekroju poprzecznym są zakończone ostrokonturowo, charakteryzują się wyższymi parametrami wytrzymałościowymi, większą sztywnością oraz większymi wartościami modułu sprężystości wzdłużnej w porównaniu z włóknami owalnymi. Większe pole powierzchni tych włókien sprawia, że poprawiona zostaje także adhezja macierzy polimerowej ze wzmacniającą ją fazą nieorganiczną [19].

\section{Sorpcja wody}

Macierz organiczna tworzywa FRC wchłania wodę na drodze dyfuzji. Cząsteczki wody wnikają w wolne obszary, utworzone pomiędzy łańcuchami makrocząsteczek polimerów, co skutkuje rozluźnieniem sieci przestrzennej materiałów. Zmiana objętości i wymiarów macierzy organicznej jest z reguły nieznaczna i może być odwracalna. Niemniej eksploatacja materiału przez cały okres użytkowa- nia znajdującego się w wilgotnym i zmiennym środowisku jamy ustnej może być przyczyną nieodwracalnych zmian parametrów fizykochemicznych materiału kompozytowego [20]. Na podstawie badań przeprowadzonych przez Brożka i wsp. stwierdzono zróżnicowany wpływ wodnego środowiska na chłonność materiałów polimerowych typu FRC [21]. Sorpcja wody wszystkich materiałów nie przekroczyła $40 \mu \mathrm{g} / \mathrm{mm}^{3}$ w czasie trwania eksperymentu, a więc spełnione zostały założenia normy PN EN ISO 10477 Stomatologia. Materiały na korony i mosty. Niemniej najmniejsze własności sorpcyjne charakterystyczne były dla materiału polietylenowego (Rycina 4).

\section{Sposób łączenia osnowy z włóknem}

Siła wiązania włókna do matrycy zależy od: budowy chemicznej włókna, składu chemicznego macierzy oraz kondycjonowania włókien na drodze chemicznej i fizycznej. Proces nasycenia, penetracji żywicy w przestrzeń pomiędzy wiązkami włókien to impregnacja. Proces ten zależy od zwilżalności powierzchni, odległości pomiędzy poszczególnymi włóknami oraz posiadanych właściwości mechanicznych.

Ścisłe przyleganie włókien między sobą sprawia, że są one słabiej zwilżane i wypełniane przez żywicę. Cząsteczki PMMA są duże, ich wielkość wynosi 30-60 $\mu \mathrm{m}$.

Stąd dystans pomiędzy włóknami jest duży, ich ilość może okazać się niewystarczająca w jednost-

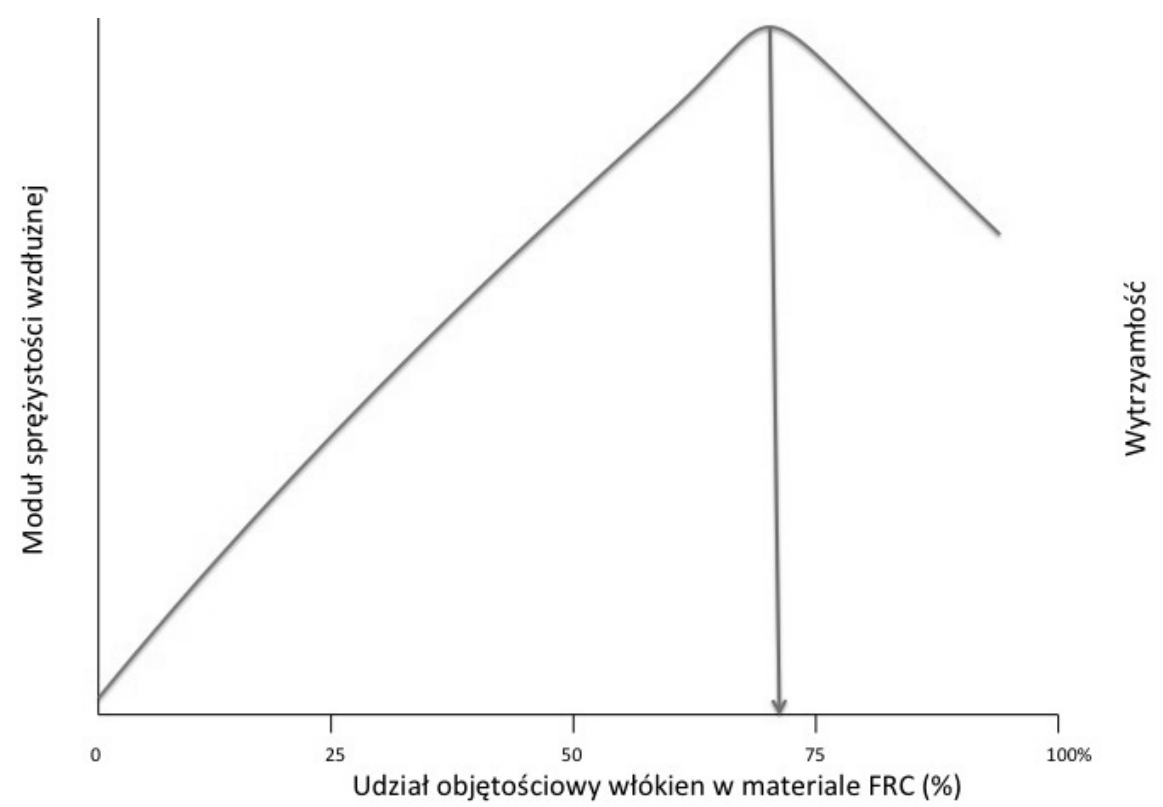

Rycina 3. Wpływ objętości procentowej włókien na moduł sprężystości wzdłużnej i wytrzymałość materiału FRC

Figure 3. The influence of the volume percentage of fibers on the elastic modulus and strength of the material FRC 


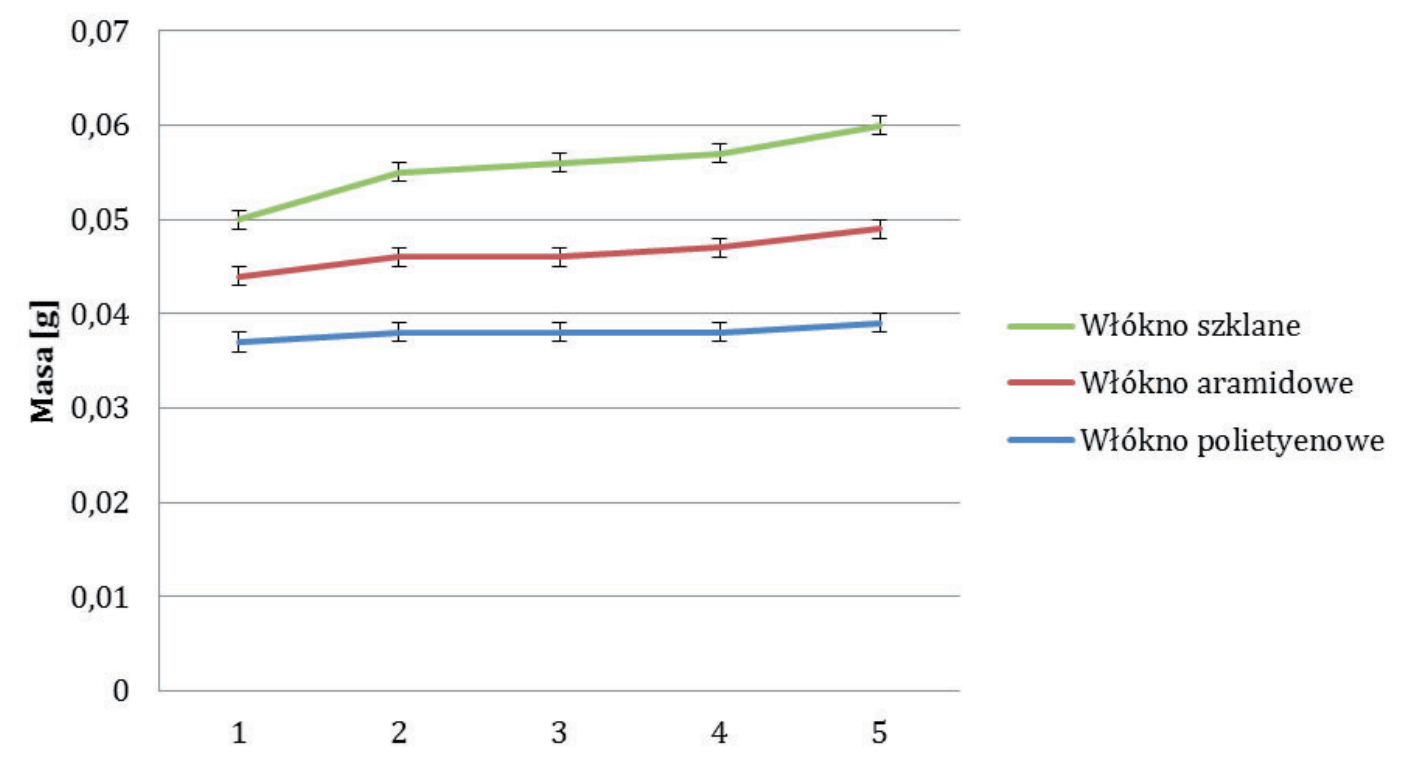

Rycina 4. Masa badanych materiałów przedstawiona w kolejnych pomiarach (po 1. dniu, 7. dniach, 14. dniach oraz 28. dniach trwania eksperymentu)

Figure 4. The weight of the tested materials presented in subsequent measurements (after 1 day, 7 days, 14 days and 28 days of the experiment)

ce objętości. W procesie preimpreganacji rozpuszcza się PMMA w roztworze, który szybko paruje. Szybkie parowanie sprawia, że powstają mikroporowatości w strukturze żywicy stwarzając dodatkowe miejsce dla włókna. Na powierzchni włókien szklanych znajdują się grupy -OH hydroksylowe, które zapewniają dobrą adhezję do materiałów żywiczych. Zdolność włókien jest zwiększana w procesie silanizacji. Silany chętnie reagują z grupami hydroksylowymi -OH włókna, jak i nieprzereagowanymi grupami winylowymi $-\mathrm{CH}=\mathrm{CH}_{2}$ żywic. Silan to czynnik posiadający przynajmniej jedną grupę Si-C lub Si-H, różne grupy organiczne mogą tworzyć reakcje z sialnem. Jedynie włókna szklane posiadają zdolność chemicznego łączenia z macierzą organiczną w procesie silanizacji.

Inne włókna stosowane w stomatologii są chemicznie obojętne. Brak aktywnych grup chemicznych (estrowych, amidowych lub hydroksylowych) powoduje jego odporność na działanie wody, wilgoci, większości substancji chemicznych, promieniowania UV oraz drobnoustrojów.

Włókna UHMWPE są niepolarne, charakteryzują się niskimi wartościami energii powierzchniowej, co zapewnia doskonałą stabilność w zmiennym i trudnym środowisku jamy ustnej. Ich inertność sprawia, że uzyskanie adhezji UHMWPE do macierzy polimerowej nie jest łatwe [22]. W celu zwiększenia siły połączenia włókien i macierzy organicznej modyfikuje się $w$ procesie oksydacji ich powierzchnie [23].
Reakcja oksydacji powoduje zwiększenie energii i powinowactwa powierzchniowego, a także siły połączenia z niektórymi polimerowymi układami hydrofilnymi w odróżnieniu do włókien niezmodyfikowanych. Poprawia się także zwilżalność w stosunku do nieaktywowanych polimerów, co zapobiega postępującym uszkodzeniom materiału, polegającym na wzajemnej utracie spójności włókien i macierzy organicznej, w wyniku działających na nie zmiennych sił odkształcających [24, 25].

\section{Podsumowanie}

Dzięki posiadanym pożądanym właściwościom mechanicznym materiały kompozytowe wzmocnione włóknem są pomocne w skutecznym rozstrzygnięciu zagadnień i problemów pojawiających się podczas leczenia stomatologicznego. Są równorzędną alternatywą dla protez stałych cementowanych konwencjonalnie, których utrzymanie na podłożu dokonuje się z wykorzystaniem retencji mechanicznej.

Uzasadnioną koniecznością staje się ustawiczne pogłębianie obszernej wiedzy teoretycznej z tego zakresu celem uzyskania bardziej satysfakcjonujących pod względem klinicznym i ekonomicznym uzupełnień protetycznych, powstałych w oparciu o rozwiązania FRC.

\section{Oświadczenia}

Oświadczenie dotyczące konfliktu interesów Autorzy deklarują brak konfliktu interesów w autorstwie oraz publikacji pracy. 
Źródła finansowania

Autorzy deklarują brak źródeł finansowania.

\section{Piśmiennictwo}

[1] Vallittu P, Ozcan M. Clinical Guide to Principles of Fiber-Reinforced Composites in Dentistry. United Kingdom: Elsevier; 2017. s. 231.

[2] He J, Vallittu PK, Lassila LV. Preparation and characterization of high radioopaque E-glass fiber-reinforced composite with iodine containing methacrylate monomer. Dental Materials. 2017;33(2):218-225.

[3] Bijelic-Donova J, Garoushi S, Lassila LV, Keulemans F, Vallittu PK. Mechanical and structural characterization of discontinuous fiber-reinforced dental resin composite. Journal of Dentistry. 2016;52:70-78.

[4] Eskitaşcioglu G, Eskitaşcioglu A, Belli S. Use of polyethylene ribbon to create a provisional fixed partial denture after immediate implant placement: a clinical report. J Prosthet Dent. 2004;91(1):11-14.

[5] Lung CY, Matinlinna JP. Aspects of silane coupling agents and surface conditioning in dentistry: An overview. Dental Materials. 2012;28(5):467-477.

[6] Matinlinna JP, Lassila LV, Özcan M, Yli-Urpo A, Vallittu PK. An introduction to silanes and their clinical applications in dentistry. International Journal of Prosthodontics. 2004;17(2):155-164.

[7] Vallittu PK. Compositional and Weave Pattern Analyses of Glass Fibers in Dental Polymer Fiber Composites. Journal of Prosthodontics. 1998;7(3):170-176.

[8] Sui G, Zhong WH, Ren X, Wang XQ, Yang XP. Structure, mechanical properties and friction behavior of UHMWPE/HDPE/carbon nanofibers. Materials Chemistry and Physics. 2009;115(1):404-412.

[9] Khan AS, Azam MT, Khan M, Mian SA, Rehman IU. An update on glass fiber dental restorative composites: A systematic review. Materials Science and Engineering: C. 2015;47:26-39.

[10] Mannocci F, Sherriff M, Watson TF, Vallittu PK.. Penetration of bonding resins into fibre-reinforced composite posts: a confocal microscopic study. Int Endod J. 2005;38(1):46-51.

[11] Frese C, Decker C, Rebholz J, Stucke K, Staehle HJ, Wolff $D$. Original and repair bond strength of fiber-reinforced composites in vitro. Dent Mater. 2014;30(4):456-462.

[12] Wolff D, Geiger S, Ding P, Staehle HJ, Frese C. Analysis of the interdiffusion of resin monomers into pre-polymerized fiber-reinforced composites. Dent Mater. 2012;28(5):541-547.

[13] Fejdyś M, Łandwijt M. Włókna techniczne wzmacniające materiały kompozytowe. Tech. Wyr. Włók. 2010;11:12-22.

[14] Karbhari VM, Strassler H. Effect of fiber architecture on flexural characteristics and fracture of fiber-reinforced dental composites. Dental Materials. 2007;23(8):960-968.

[15] Dyer SR, Lassila LV, Jokinen M, Vallittu PK. Effect of cross-sectional design on the modulus of elasticity and toughness of fiber-reinforced composite materials. The Journal of Prosthetic Dentistry. 2005;94(3):219-226.
[16] Rezvani MB, Atai M, Hamze F, Hajrezai R. The effect of silica nanoparticles on the mechanical properties of fiber-reinforced composite resins. J Dent Res. 2016;10(2):112-117.

[17] Vallittu PK. High-aspect ratio fillers: Fiber-reinforced composites and their anisotropic properties. Dental Materials. 2015;31(1):1-7.

[18] Lassila LV, Tanner J, Le Bell A-M, Narva K, Vallittu PK. Flexural properties of fiber reinforced root canal posts. Dental Materials. 2004;20(1):29- 36.

[19] Yang L, Liu X, Wu Z, Wang R. Effects of triangle-shape fiber on the transverse mechanical properties of unidirectional carbon fiber reinforced plastics. Composite Structures. 2016;152:617-625.

[20] Łukomska-Szymańska M, Kleczewska J, Nowak J, et al. Mechanical Properties of Calcium Fluoride-Based Composite Materials. Biomed Res Int. 2016:1-8.

[21] Brożek R, Paszyńska E, Koczorowski R, Dorocka-Bobkowska B. Wchłanianie wody przez materiały polimerowe, stosowane w stałych i ruchomych protezach zębowych - badania eksperymentalne. Dental Forum. 2018;20(1):25-30.

[22] Oosterom R, Ahmed TJ, Poulis JA, Bersee HE. Adhesion performance of UHMWPE after different surface modification techniques. Medical Engineering \& Physics. 2006;28(4):323-330.

[23] Debnath S, Ranade R, Wunder SL, Baran GR, Zhang $J$, Fisher ER. Chemical surface treatment of ultrahigh molecular weight polyethylene for improved adhesion to methacrylate resins. Journal of Applied Polymer Science. 2005;96(5):1564.

[24] Bahramian N, Atai M, Naimi-Jamal MR. Ultra-high-molecular-weight polyethylene fiber reinforced dental composites: Effect of fiber surface treatment on mechanical properties of the composites. Dental Materials. 2015;31(9):1022- 1029.

[25] Sokołowski J, Szynkowska MI, Kleczewska J, Kowalski Z, Sobczak-Kupiec A, Pawlaczyk A, et al. Evaluation of resin composites modified with nanogold and nanosilver. Acta Bioeng Biomech. 2014;16(1):51-61.

Zaakceptowano do edycji: 2018-10-16 Zaakceptowano do publikacji: 2018-12-05

Adres do korespondencji:

Rafał Brożek

Klinika Gerostomatologii i Patologii Jamy Ustnej

Collegium Stomatologicum

ul. Bukowska 70, 60-812 Poznań

tel.: 6185470 78, e-mail: broz@ump.edu.pl 